\title{
Effect of Climate Change on Wheat Based Cropping System in India: A Review
}

\author{
Aruna Devi Ahirwar ${ }^{1}$, S.K. Ahirwar ${ }^{2 *}$ and S.M. Kurmvanshi ${ }^{3}$ \\ ${ }^{1}(P B \& G), J N K V V, Z A R S$, Chhindwara (M.P.), India \\ ${ }^{2}$ (Agronomy) - KVK, Chhindwara (M.P.), India \\ ${ }^{3}$ (Agronomy) College of Agriculture, JNKVV, Rewa (M.P.), India \\ *Corresponding author
}

\section{A B S T R A C T}

A wheat growth model that includes the direct responses of canopy photosynthesis and transpiration to elevated $\mathrm{CO}_{2}$, and the response of crop growth to water stress has been

Keywords

Climate change,

Wheat based cropping system

Article Info

Accepted:

26 September 2018

Available Online:

10 October 2018 developed and tested. Sensitivity analyses show that different cultivars have quite different responses to changes in ambient air temperature, ambient $\mathrm{CO}_{2}$ concentration and rainfall. Because crops reach maturity earlier under higher temperature, an increase of $3{ }^{\circ} \mathrm{C}$ may not impose further water stress to growth of a wheat crop. Climate change, which is simple terms refers to the rise in mean minimum and maximum temperature, elevation in $\mathrm{CO}_{2}$ and other green house gases, coupled with less/more or elastic rainfall patterns is a matter of greater concern for the agrarian ecologies. Climate change is predicted to bring about increased temperature across the world in the range $1.6^{\circ} \mathrm{C}$ to $6^{\circ} \mathrm{C}$ by 2050 . And, although rainfall is predicted to increase globally, some areas will receive less annual or uncertain rainfall while others may records significant increase, with associated change in the timing of rains and lengths of dry seasons. There is key factors for significantly impact to mitigate stress conditions of the climate, i.e. Conservation agriculture, zero tillage, Raised bed planting technology, Direct seeded rice, Crop diversification, Leaf colour chart in Rice and Wheat, Integrated Nutrient Management, Weed Management and Water management etc.

\section{Introduction}

Wheat [Triticum aestivum (L.)] is favored by long cool, moist weather followed by dry and warm weather/rabi season. Wheat is an essential commodity for human civilization and is planted annually in an area of around 229 million hectares across the world. Wheat provides $21 \%$ of the food calories and $20 \%$ of the protein for more than 4.5 billion people in 94 countries. Wheat research in India began in a systematic way more than a hundred years ago. The coordinated system of multi-location research to address the needs of different agroecological zones in wheat has been in operation for more than fifty years now.

During this period India witnessed the dramatic successes of the green revolution and has been able to rise from a deficit state to a self-sufficient one going on to have surplus production at times. India harvested a record 98 million tonnes of wheat during the crop year 2013-14 with a productivity level of 
3144kg/ha. (Vision- 2050) Wheat varieties are being grown in this country under different environmental influence with regards to the ecology conditions. India is the second largest produces of wheat in the world and plays a key role in food and nutritional security next only to china. Wheat contributes about $35 \%$ of total cereal production in country. The demand for food grains is estimated at $250 \mathrm{mt}$ by the end of XI plan period. The task is quite challenging and the option available are very limited in view of plateauing rend of yield in high productive area, decreasing and degrading land, water, labour and other inputs.

Hence, emphasis needs to be laid on identification of suitable cropping system with higher and stable yields and/or profit in different agro ecological regions. The change in climate has been attributed to global warming and has many facts, including changes in long term trend in temperature and rainfall regimes as well as increasing year to year variability and a greater prevalence of extreme events.

Agricultural system will be affected by both short and long term changes in climate and will have serious implication on rural livelihoods, particularly of the poor being the most vulnerable. The impact of climate change posses' serious threats to productivity and sustainability, therefore wheat based cropping system including wheat-rice system, the backbone of food security of India. Conservation agriculture involving continuous minimum mechanical soil disturbance, permanent organic soil cover and diversified crop rotation provides opportunity of mitigation greenhouse gas emission and climate change adoption.

Climate change, which is simple terms refers to the rise in mean minimum and maximum temperature, elevation in $\mathrm{CO}_{2}$ and other greenhouse gases, coupled with less/more or elastic rainfall patterns is a matter of greater concern for the agrarian ecologies. Climate change is predicted to bring about increased temperature across the world in the range $1.6^{0}$ $\mathrm{C}$ to $6^{0} \mathrm{C}$ by 2050 . And, although rainfall is predicted to increase globally, some areas will receive less annual rainfall while others may records significant increase, with associated change in the timing of rains and lengths of dry seasons. The frequency and durations of the extreme environmental pattern will also increase.

In India began All India Coordinated Wheat Improvement Project (AICWIP) in 1964 at IARI, New Delhi and was elevated to the status of Directorate of Wheat Research (DWR) in 1978. The Directorate moved to the present location at Karnal in 1990. And with addition of Barley Network it was renamed as All India Coordinated Wheat and Barley Improvement Project (AICW\&BIP). The AICW\&BIP work has resulted in the release of 412 wheat varieties, tailored for specific growing situations in the six wheat zones of the country. Starting with the first semi-dwarf introductions like Lerma Rojo, Sonora 64 and their further selections like Chhoti Lerma, Kalyansona and Sonalika, the programme went on to release varieties which became extremely popular and occupied large acreage.

These mega varieties include C 306, HD 2009, WL 711, UP 262, HUW 234, HD 2189, WH 147, Lok 1, HI 617 (Sujata), HD 2285, HD 2329, PBW 343, Raj 3765, PBW 502, HD 2733, DBW 17, PBW 550, GW 273, GW 322, GW 496 in bread wheat and Raj 1555, PBW 34, HI 8498, PDW 291 and PDW 233 in durum wheat. Many varieties such as NP 4, Kalyansona, Sonalika, Sharbati Sonora, WL 711, HD 1220, HD 1931 'SIB', HD 2009, HD 2172, UP 262 etc., developed under the project stepped beyond after well national boundaries to be grown by farmers in other countries. 
Current scenario of wheat based cropping system

The actual rainfall data were used for wheat crop yield for inter -relationship during ten years (2000 to 2010). Descriptive statistical analysis was made especially for the correlation, coefficient of variation. The wheat crop yield is dependent on climatic situation in India mainly on south west monsoon. The pattern of rainfall gives current scenario for production of wheat crops. It is easily to formulate and initiate appropriate policy measures if the data with regard to the trend of production in obtained and analyzed in advance (Koshal, 2014) (Fig. 1-3; Table 1 and 2).

\section{Relationship between rainfall and wheat crop}

The yearly rainfall data for the ten years were computed considering the crop growing season length based on planting and harvest dates. The analysis of wheat yield with rainfall $\mathrm{CV}=0.05 \%$ was observed and coefficient of correlation between rainfall and yield was 0.16 .

Although wheat is grown during non-monsoon months, its production shows a rather weak but significant correlation with monsoon rainfall is 0.16 for wheat.

The relationship between year wise rainfall and yield of wheat was computed which less than linear function (Koshal, A. K., 2014).

\section{Global warming}

The Intergovernmental Panel on Climate Change (IPCC), an international body of over 3000 experts, indicates that wheat production of India will drop significantly because of climate change. A $1.5{ }^{\circ} \mathrm{C}$ rise and $2 \mathrm{~mm}$ increase in precipitation could result in a decline in rice yield by $3-15$ per cent. The most serious climate change risk to the Indian economy and its people is the increase intensity, frequency and geographical coverage of drought. High temperature, increase evapo-transpiration and decrease winter precipitation may bring about more droughts. Preference of wheat based cropping system in different parts is based on location advantage facilities for i.e. wheat -rice system are practiced in irrigated ecology.

Wheat is the most widely cultivated of all cereals. It is grown under various climate conditions between $47^{0} \mathrm{~S}$ and $57^{0} \mathrm{~N}$ latitudes.

\section{Agro-climatic zone where are significantly dominant of wheat crop}

\section{Northern hills zone}

It covers the humid western Himalayan region and includes Jammu and Kashmir, Himachal Pradesh, Uttaranchal, Sikkim and Arunachal Pradesh. Nearly $4 \%$ of area and 3\% of production of the Indian wheat is contributed by this zone. Crop duration are long starting from Oct -Nov end in May/June.

\section{Northern hills zone}

It covers the humid western Himalayan region and includes Jammu and Kashmir, Himachal Pradesh, Uttaranchal, Sikkim and Arunachal Pradesh. Nearly $4 \%$ of area and 3\% of production of the Indian wheat is contributed by this zone. Crop duration are long starting from Oct -Nov end in May/June.

\section{North western plains zone}

This zone covers part of Sub humid satlajGanga Allubial plains and arid Western plains comprises Punjab, Haryana, Delhi, Rajasthan, Western U.P. It is contributes nearly $45 \%$ production from $37 \%$ of total area under wheat in India. 


\section{North eastern plains zone}

This zone covers Sub humid satlaj-Ganga Allubial plains, humid Bengal Assam basin, humid eastern Himalayan region and Bay of Island.

The zone comprises eastern U.P., Bihar, Orissa, West bangal, Assam, Sikkim, Arunachal Pradesh and other far eastern states and contributes about $24 \%$ of total production of wheat from $27 \%$ area.

\section{Central zone}

Parts of arid, Western plains, semi-arid lava plateau, central highland. India and sub humid to humid eastern and south eastern upland comprises this zone.

This zone contributes nearly $17 \%$ area and $13 \%$ production. Crop is sown during Oct and harvested by March. T. durum is preferred this zone.

\section{Peninsular zone}

The Daccan plateau, western Ghats, central highlands and Karnataka plateau comprises this zone. The zone contributes $6 \%$ area and $2.5 \%$ production of wheat. T. aestivum, $T$. durum and $T$. dicocum cultivated this zone.

\section{Southern hills zone}

This zone comprises hilly areas Tamilnadu and Kerala. Wheat has minor importance with respect to area and production.

\section{Issues in wheat based cropping system}

Rice-Wheat sequence is the most widely adopted cropping system in the country and has become mainstay of cereal production. The U.P, Punjab, Haryana, Bihar, M.P. and West Bengal states are the heartland of this cropping system with an estimated area of about 12 million ha. This system is spread in 123 districts of these states and contributes about 25 and $42 \%$ of the total national rice and wheat production, respectively.

The specific issues needing careful attention of researchers for dominant wheat based cropping system could be listed as below:-

Difficulties for tillage and poor crop stand in wheat cultivation.

Development of multiple nutrients deficiency.

Buildup of infestation of Phalaris minor and wild oat in wheat.

Imbalance or low use of fertilizers.

Lack of appropriate varietal adjustment for crop components.

\section{Effect of climate change on pollination and seed set}

Abundant and timely pollen production is a key requirement for reproductive success. Inter annual variation in pollen production results in variable seed production in several temperate species (Bramlett, 1981; Burns and Honkala, 1990). Differential responses to high $\mathrm{CO}_{2}$ and temperature on the male and female reproductive system and their effects on pollen production, release, movement and seed sets may have important implications on population dynamics.

Seed crops comprise nearly $70 \%$ of food and feed requirement of the world.

An increase of $1{ }^{\circ} \mathrm{C}$ in mean temperature is estimated to reduce the annual wheat production by 4-5 million ton in the country. Overall cereal productivity is expected to decrease by $10-40 \%$ by 2100 (Trust, 2009). 
Table.1 Area, production and productivity from 1950-51 to 2015-16

\begin{tabular}{|l|c|c|c|}
\hline Year & Area (million ha) & Production (million tonn) & Productivity (q/ha) \\
\hline $\mathbf{1 9 5 0 - 5 1}$ & 9.8 & 6.5 & 6.63 \\
\hline $\mathbf{1 9 6 0 - 6 1}$ & 12.9 & 11 & 8.51 \\
\hline $\mathbf{1 9 6 7 - 6 8} *$ & 14.9 & 16.5 & 11.03 \\
\hline $\mathbf{1 9 7 0 - 7 1}$ & 18.2 & 23.8 & 13.07 \\
\hline $\mathbf{1 9 8 0 - 8 1}$ & 22.3 & 36.3 & 16.30 \\
\hline $\mathbf{1 9 9 0 - 9 1}$ & 24.2 & 55.1 & 22.81 \\
\hline $\mathbf{1 9 9 9 - 2 0 0 0}$ & 27.5 & 76.4 & 27.78 \\
\hline $\mathbf{2 0 0 0 - 2 0 0 1}$ & 25.7 & 69.7 & 27.08 \\
\hline $\mathbf{2 0 0 2 - 0 3}$ & 25.2 & 69.3 & 27.47 \\
\hline $\mathbf{2 0 0 3 - 0 4}$ & 25.2 & 65.8 & 26.11 \\
\hline $\mathbf{2 0 0 4 - 0 5}$ & 26.6 & 72 & 27.07 \\
\hline $\mathbf{2 0 0 5 - 0 6}$ & 26 & 69.5 & 27.75 \\
\hline $\mathbf{2 0 0 6 - 0 7}$ & 27.9 & 75.8 & 27.00 \\
\hline $\mathbf{2 0 0 7 - 0 8}$ & 27.7 & 78.4 & 28.00 \\
\hline $\mathbf{2 0 0 8 - 0 9}$ & 27.75 & 80.6 & 29.07 \\
\hline $\mathbf{2 0 0 9 - 1 0}$ & 28.46 & 80.51 & 29.29 \\
\hline $\mathbf{2 0 1 0 - 1 1}$ & 29.07 & 86.89 & 31.77 \\
\hline $\mathbf{2 0 1 1 - 1 2}$ & 29.86 & 94.88 & 31.17 \\
\hline $\mathbf{2 0 1 2 - 1 3}$ & 30.00 & 91.51 & 31.44 \\
\hline $\mathbf{2 0 1 3 - 1 4}$ & 30.83 & 96.95 & 27.13 \\
\hline $\mathbf{2 0 1 4 - 1 5}$ & 31.89 & 86.53 & 27.60 \\
\hline $\mathbf{2 0 1 5 - 1 6}$ & 31.7 & 88.00 & \\
\hline
\end{tabular}

Table.2 Relationship between average actual Rainfall $(\mathrm{mm})$ and wheat yield $(\mathrm{kg} / \mathrm{ha})$ in India (Year 2000-01 to $2010-11$ )

\begin{tabular}{|l|}
\hline \multicolumn{1}{|c|}{ Years } \\
\hline 2000 \\
\hline 2001 \\
\hline 2002 \\
\hline 2003 \\
\hline 2004 \\
\hline 2005 \\
\hline 2006 \\
\hline 2007 \\
\hline 2008 \\
\hline 2009 \\
\hline 2010 \\
\hline Standard deviation \\
\hline Mean \\
\hline Corr. Coeffi. \\
\hline CV \\
\hline
\end{tabular}

\begin{tabular}{|c|c|}
\hline Actual Rainfall (mm) & Wheat yield (kg/ha) \\
\hline 607.7 & 3258 \\
\hline 791.6 & 3197 \\
\hline 794.1 & 3157 \\
\hline 788.9 & 3091 \\
\hline 781.0 & 3047 \\
\hline 800.9 & 3119 \\
\hline 689.2 & 3282 \\
\hline 851.9 & 3416 \\
\hline 939.1 & 3456 \\
\hline 673.6 & 3414 \\
\hline 801.1 & 3580 \\
\hline 77.84 & 171.90 \\
\hline- & 3274.27 \\
\hline 0.12 & 0.16 \\
\hline
\end{tabular}

2015-Warmest Global Year on Record (since 1880) - Colors indicate temperature anomalies (NASA/NOAA; 20 January 2016). 
Fig.1 Area, production and productivity in India during 1950-51 to 2015-16

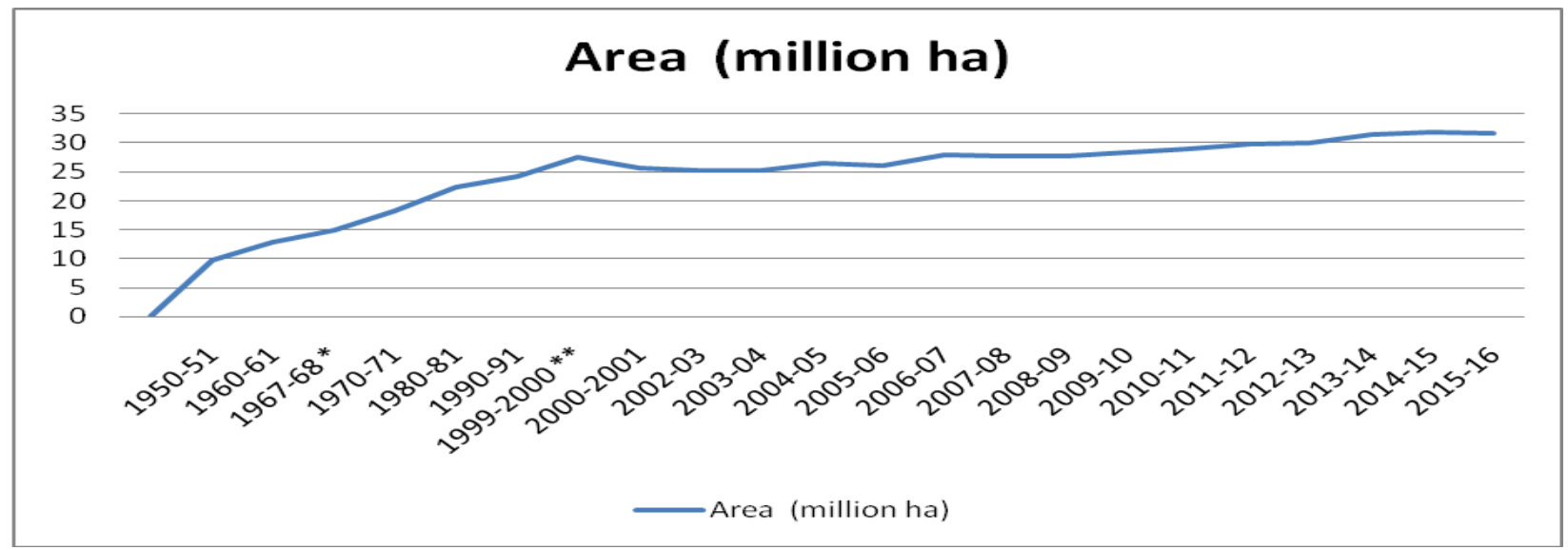

Fig.2 Area, production and productivity in India during 1950-51 to 2015-16

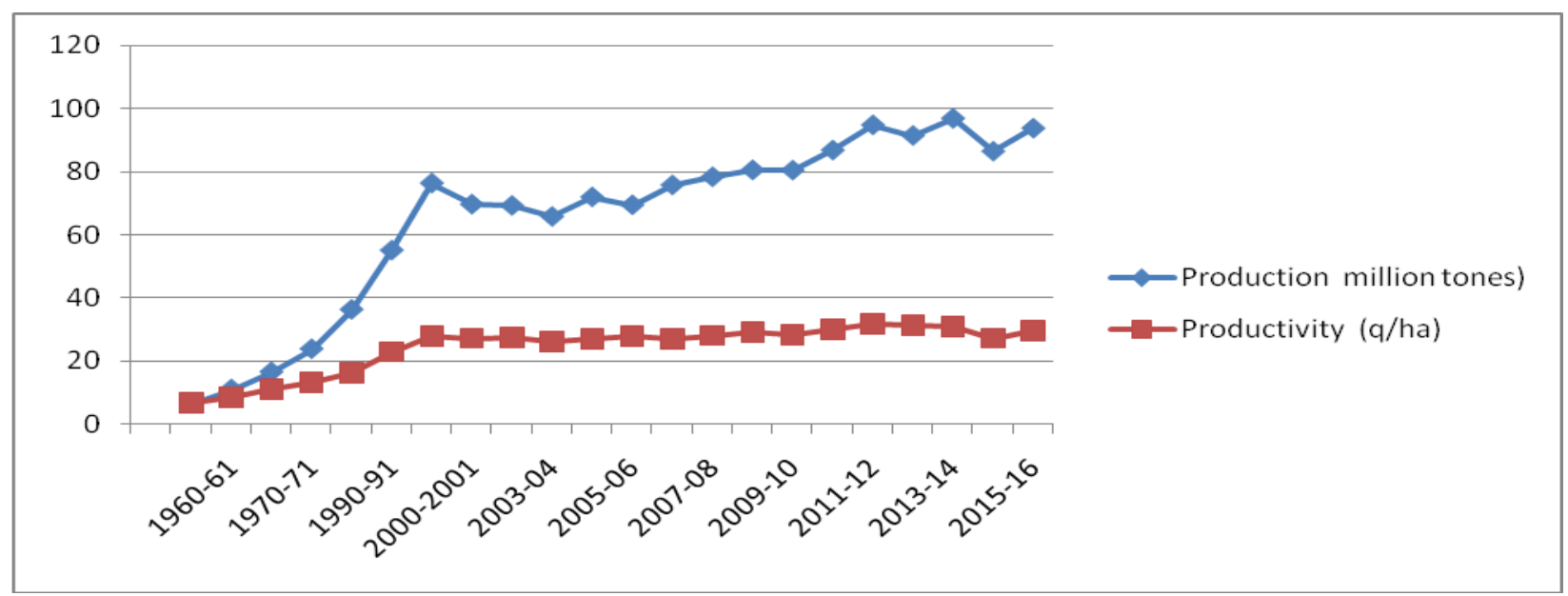

Fig.3 Relationship between average actual Rainfall ( $\mathrm{mm})$ and wheat yield $(\mathrm{kg} / \mathrm{ha})$

(Year 2000-01 to $2010-11$ )

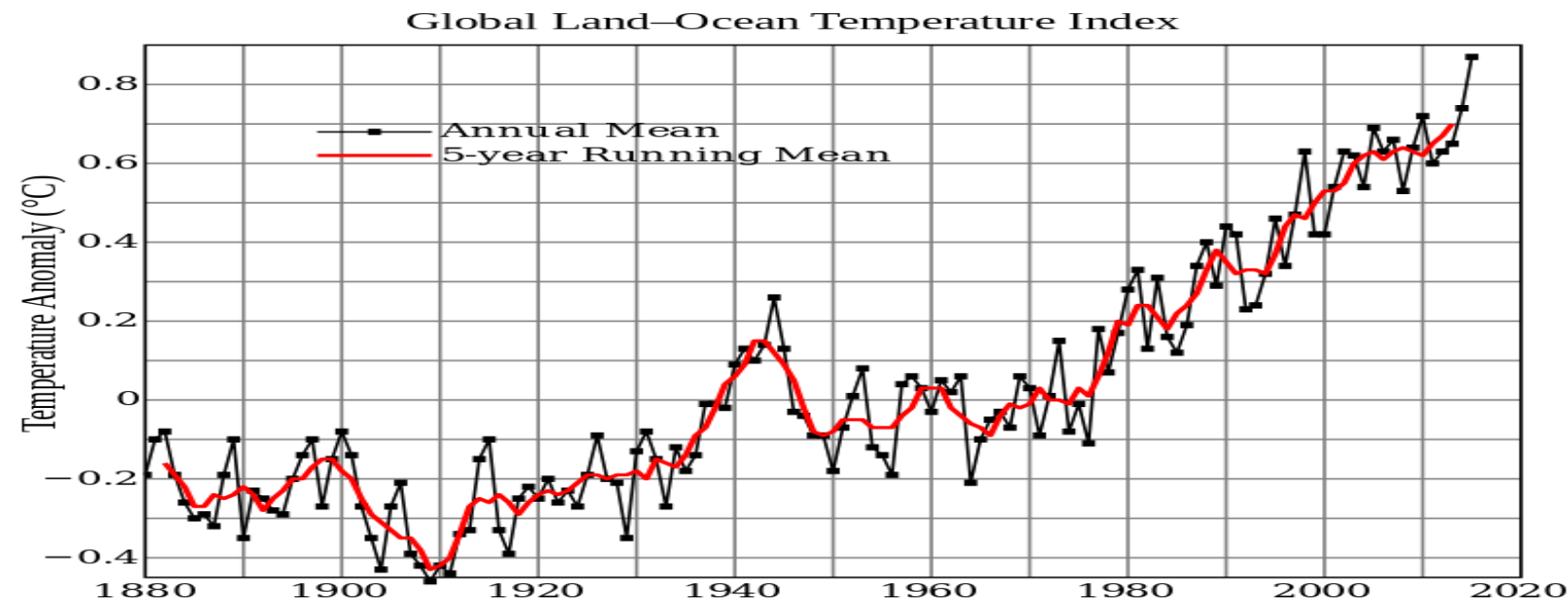




\section{Global warming}

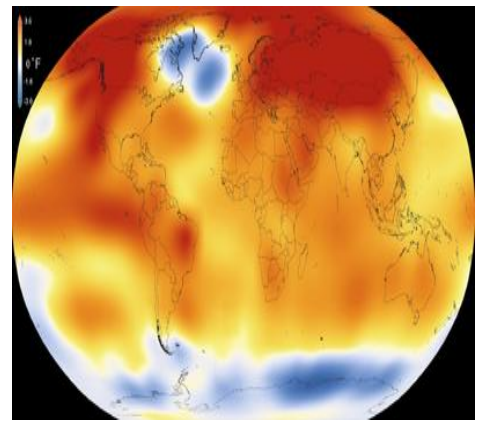

Management of wheat based cropping system

The wheat based cropping system will continue to be important cropping system in India in the years to come. Therefore, there is a strong need to monitor these systems in terms of nutrient dynamics and to develop efficient integrated nutrient supply and management system in different regions using locally available resources like composts, FYM, farm wastes, crop residues and green manures. There is also a need to monitor insects, disease and weed problems, water table and water harvesting techniques.

\section{Conservation agriculture}

The conservation agriculture is a practice in which there conditions of minimum soil disturbance, surface residue cover of at least $30 \%$ and crop diversification, must be satisfied. Heaving crop residues on soil surface seems to be a better option than incorporation as it residues soil erosion and soil evaporation, avoids short term nutrient tie up and suppresses weeds. Moreover, the slower decomposition compared with incorporation also helps build up soil organic carbon (Havlin et al., 1990; Hooker et al., 1982; Unger 1991; Wood et al., 1990). Crop residues and tillage practices also influence the weed germination and establishment. Tillage is mainly practiced to prepare seedbed and to control weeds, which has already germinated. But the tillage is also responsible for stimulation of the weed germination and emergence of many weeds through brief exposure to light (Ballard et al., 1992). Crop residues may influence the weed seed reserve in the soil directly or indirectly and also the efficiency of soil applied herbicides (Crutchfield et al., 1986) residues type also influences weed growth (Eguchi and Hirano, 1971) found that rice straw mulch reduced the population of weed in wheat.

\section{Zero tillage}

This is a conservation technology in which the crop is directly seeded into the undisturbed soil after harvesting previous crop using a specially designed macline. In this preparation practices for wheat after rice involves as many as 10-12 tractor passes. Changing to a zero till system on 1 ha of land would save 98 liters of diesel and approximately 1 million liters of irrigation water besides reducing about a quarter tones less emission of carbon dioxide, the principal contribution to global warming. In view of the saving of cost, energy, time and drudgery, the benefit cost ratio has been reported to be highest for zero tillage (Sharma et al., 2004) thereby increasing the profit margin of the farmers. Other benefit of this technology is the lower incidence of termite (Sharma et al., 2004b), karnal bunt (Sharma et al., 2007) and irrigation water saving compared to conventional tillage. 


\section{Raised bed planting technology}

In this conservation technology, the crop is grown on raised beds. This technology saves water, nitrogen (Sharma et al., 2005) and will also helps save energy, time, drudgery and the cost, if permanent beds are used which can be easily adopted in almost all the cropping system other than rice-wheat, but may require site specific fine tuning, for e.g. in the case of black cotton soils, instead of narrow beds of about $70 \mathrm{~cm}$, the broad beds of about $140 \mathrm{~cm}$ may prove beneficial. In addition the furrow which is generally around $30 \mathrm{~cm}$ wide may be widened to about $50 \mathrm{~cm}$ to quickly drain out water from field in the event of heavy rainfall. In addition, bed planting will be helpful to avoid temporary soil aeration problem after irrigation in black soil leading to better productivity of crops. However, greater incidence of powdery mildew (Sharma et al., 2004a) and termite (Sharma et al., 2004b) may need to be taken care off when the crop is grown on beds.

\section{Direct seeded rice}

Direct seeding has advantages of faster and easier planting, reduced labour and less drudgery with earlier crop maturity by 7-10 days more efficient water use and higher tolerance of water deficit, less methane emission and often higher profit in areas with an assured water supply. Weed control is a major issue in direct seeded rice and to overcome this problem, intensive efforts are being made by the weed scientists. The seed rate for dry and wet (Sharma et al., 2003b) direct seeding may be kept around $20 \mathrm{Kg} / \mathrm{ha}$. The experience over the past about are one and a half decades have shown that all the rice varieties are not suitable for direct dry seeding (Chhokar et al., 2014) and it may not be possible in all soil types. It will work in soils where water tends to stagnate for 2-3 days after irrigation with effective weed control.

\section{Crop diversification}

Diversification is growing a range of crops suited to different sowing and harvesting times, assists in achieving sustainable productivity by allowing farmers to employ biological cycles to minimize inputs, maximize yields, conserve the resource base and reduce risk due to both environmental and economic factors. The resources conserving technologies such as bed planting and zero tillage expand the windows of crop diversification. The farmers of rice-wheat belt have taken the initiative to diversify their agriculture by including short duration crops such as potato, soybean, black gram, green gram, cowpea, pea, mustered, and maize into different combinations. Such diversification would not only improve income, employment and soil health but also reduce water use and greenhouse gases emission and more adaptability to heat and water stress.

\section{Leaf colour chart in rice and wheat}

Leaf colour is a fairly good indicator of the nitrogen states of plant. Nitrogen uses can be optimized by matching its supply to the crop demand as observed through change in the leaf chlorophyll content and leaf colour. The monitoring of leaf colour using leaf colour chart help in the determination of right dose of nitrogen application. Use of leaf colour chart in simple, easy and cheap under all situation. The studies indicate that nitrogen can be saved from $10-15 \%$ using the leaf colour chart.

\section{Integrated nutrient management}

Food security and soil health are two important concerns in Indian agriculture. Particularly wheat based cropping system includes scientific management of these sources of nutrients for securing optimum crop yield and soil fertility improvement. 
According to Roy and Ange (1991), the basic concept underlying integrated plant nutrient supply and management system is the maintenance or adjustment of soil fertility and of plant nutrient supply to an optimum level for sustaining the desired crop productivity through optimization of the benefits from all possible sources of plant nutrient in an integrated manner. Economics viability and ecological sustainability are also major consideration in INM. In a holistic approach, the INM practices are designed and adopted to increase the quantity and of crop produce, decrease nutrient losses, increase the efficiency of applied and native nutrients, improve soil health, economize on fertilizer use, protect the environment and minimize the energy consumption in agriculture.

\section{Weed management}

Climate change will also affect the weed communities in the wheat based cropping system. A review on the effect of weed growth on yield suggested losses in the range $28-74 \%$ in rice and $15-80 \%$ in wheat. Improving weed control in farmers' field has shown to increase rice and wheat yield by 15 $30 \%$. North West India annually contributes more than $50-60 \%$ of rice and wheat to the control food grain reserve, making it the bread basket of the country. Therefore, if productivity of these crops is affected, Indian food security is based to be affected. (Wheat weed name) IWM strategies need to be developed which target the prevention of weed invasion recruitment and reproduction.

\section{Green seeker technology}

Compared to leaf colour chart which is qualitative index and determines the nitrogen need of the plant by observing leaf colour, the green seeker scans the crop canopy for ground cover and the health of that cover and is a quantitative method. By using a rich strip it can be determined whether the rest of the field needs additional nitrogen or not (Bijay singh et al., 2011, Bijay singh et al., 2012). The studies in both rice and wheat showed that more than $20 \%$ nitrogen can be saved in rice and more than $15 \%$ nitrogen can be saved in wheat (Sharma et al., 2009) without yield penalty in both the crops. This technology has also been useful in precise phenotyping of quantitative stripe rust reaction (Arora et al., 2014) in wheat.

\section{Water management}

Water is an important factor for any crop growing, without water not possible to produce crop. It will be must practice in rainy season to made reservoir for the re-charging of earth and moisture retention for cropping period.

The simulations in this review took into account the effects of $\mathrm{CO}_{2}$, air temperature, incident solar radiation and soil moisture on crop growth, water-use and development. They indicated that while doubling present atmospheric $\mathrm{CO}_{2}$ concentration would lead to increases of between 28 and $43 \%$ in aboveground biomass is decreases. Therefore selection of suitable cultivars/ technology will be one of the key strategies to cope with climate change.

\section{References}

(NASA/NOAA; 20 January 2016).

Arora, A. K., Venkatesh, R. K., Sharma, M. S., Saharan, N., Dilbaghi, I., Sharma, and Tiwari, R. 2014. Evaluating vegetation indices for precision phenotyping of quantitative stripe rust reaction in wheat. Journal of Wheat Research. 6(1): 74-80.

Ballard, C.L., Scopel, R. A., Sanchez, A. L., and Radosevich, S. R. 1992. Photomorphogenic processes in the 
agricultural

environment.

Photochemistry and Photobiology 56: $777-488$

Barnett, J. 1976. Cone and seed maturation of southern pines. Research paper 50-122. USDA Forest Service, Washington, D.C.

Bijay Singh, Sharma, R. K., Jaspreet Kaur, Jat, M. L., Martin, K. L., Yadvinder Singh, Varinder Pal Singh, Thind, H. S., Uppal, H. S., Khurana, H. S., Monika Vashistha, Raun, W. R. and Gupta Raj. 2012. Optimal Sensor-based Nitrogen Management for irrigation wheat in the Indo- Gangatic Plains. Better Crops.96 (3): $18-20$.

Bijay, S., Sharma, R. K., Kaur, Jaspreet, Jat, M. L., Martin, K. L., Yadvinder Singh, Varinder, Pal Singh, Parvesh Chandna, Choudhary, O. P., Gupta, R. K., Thind, H. S., Jagmohan Singh, H. S., Uppal, H. S., Khurana, Ajay Kumar, R. K., Uppal, Monika Vashistha, Raun, W. R. and Raj Gupta. 2011. Assessment of nitrogen management strategy using an optical sensor for irrigated wheat. Agronomy Sust. Development 31: 589-603.

Bramlett, D. 1981. Effectiveness of wind pollination in seed orchards. Pollen management Hand book, Agriculture hand book 587, E Franklin (ed), US Department of Agriculture, Washington, D.C. Pp. 52-56.

Burns, R. M. and Honkala, B. 1990. Silvies of North America, conifers. Agriculture Hand book 654, US Department of Agriculture, Washington, D.C

Chhokar R. S., Sharma, R. K., Gathala, M. K, and Pundir, A. K. 2014. Effects of crop Establishment Techniques on weeds and Rice yield. Crop Pritection. 64: 7-12.

Crutchfield, D. A., Wicks, G. A. and Burnside, O. C. 1986. Effect of winter wheat straw mulch level on weed control. Weed Science. 34: 110-114.
Eguchi, H. and Hirano, J. 1971. Effect of combinations of tillage and non-tillage, straw mulching and fertilization on weed communities in rice-wheat cropping. Weed Research. 12:36-39.

Greenwood, M. 1980. Reproductive development in loblolly pine. The early development of male and female strobili in relation ti the long shoot growth behavior. American journal of Botany. 67:1414-1422.

Havlin, J. L., Kissel, D. E., Maddux, L. D., Claassen, M. M. and Long, J. H. 1990. Crop rotation and tillage effects on soil organic carbon and nitrogen. Soil Science Society of America Journal. 54: 448-452.

Hooker, M. L., Herron, G. M. and Penas. P. 1982. Effects of residue burning, removal and incorporation on irrigated cereal crop yields and soil chemical properties. Soil Science Society of America Journal. 46: 122-126.

Jat, M. L., Pal, S. S., Subba, Rao, A. V. M., Sirrohi, Kuldip, Sharma, S. K. and Gupta, R. K., 2004. Leser land the precursor technology for resource conservation in irrigated ecosystem of India. Abstract National conference on "Conservation Agriculture conserving resources enhancing productivity" September 22-23, 2004, New Delhi. Pp. 9-10.

Koshal, A. K. (2014) Changing current scenario of rice wheat system in indo Gangetic plain of India. International Journal of Scientific and Research Publications, Vol. 4, (31).

Senapati, M. P., Behera, B. and Maihra, S. R., (2013) Impact of climate change on Indian agriculture \& its mitigating priorities. American journals of Environment protection, 1(4): 109-111.

Sharma, R. K., Chhokar, R. S. and Chauhan, D. S. 2004. Zero tillage technology in rice-wheat system retrospect and 
prospects. Indian Farming. 54(4): 1217.

Sharma, A. K., Babu, K. S., Sharma, R. K. and Kamlesh Kumar. 2007. Effect of tillage practices on Tiletia indica Mitra (Karnal bunt) disease of wheat in ricewheat rotation on the Indo-Gangetic Plains. Crop protection. 26(2007): 818821.

Sharma, A. K., Sharma, R. K. and Babu, K. S. 2004a. Effect of planting option and irrigation schedules on development of powdery mildew and yield of wheat in the North Western plains of India. Crop protection. 23(3): 249-253.

Sharma, R. K, Chhokar, R. S., Babu, K. S. 2003b. Seed rate in direct seeded rice. Rwis. 47: 2-3

Sharma, R. K., Babu, K. S., Chhokar, R. S., and Sharma, A. K. 2004b. Effect of tillage on termite, weed incidence and productivity of spring wheat in ricewheat system of North Western plains of India. Crop protection. 23(11): 10491054.
Sharma, R. K., Chhokar, R. S., Gathala, M. K., Vivek Kumar, Pundir, A. K., and Mogia. 2003a. Direct seeded rice a distinct possibility. Indian Wheat Newsletter. 9(2): 5

Ttust for Advancement of Agricultural Sciences 2009. Brain storming Workshop on climate change, soil quality and food security proceeding and recommendation. August 11, 2009.

Unger, P. W. 1991. Organic matter, nutrient and $\mathrm{PH}$ distribution in no-end conventional tillage semi-arid soils. Agronomy Journal. 83:186-189.

Vision 2050, Indian Institute of Wheat and Barley Research (Indian Council of Agricultural Research) P.O. Box - 158, Agrasain Marg Karnal-132 001, Haryana

Wood, C. W., Westfall, D. G., Peterson, G. A., and I. C., Burke. 1990. Impact of cropping intensity on carbon and nitrogen mineralization under no-till dry land agro ecosystem. Agronomy Journal. 82: 1115-1120.

\section{How to cite this article:}

Aruna Devi Ahirwar, S.K. Ahirwar and Kurmvanshi, S.M. 2018. Effect of Climate Change on Wheat Based Cropping System in India: A Review. Int.J.Curr.Microbiol.App.Sci. 7(10): 35893599. doi: https://doi.org/10.20546/ijcmas.2018.710.416 